\title{
PENGARUH LIKUIDITAS DAN MODAL KERJA TERHADAP PROFITABILITAS PADA PERUSAHAAN INDUSTRI BARANG KOSUMSI
}

\author{
Ni Kadek Sugiartini ${ }^{1}$ \\ Sayu Ketut Sutrisna Dewi ${ }^{2}$ \\ ${ }^{1,2}$ Fakultas Ekonomi dan Bisnis, Universitas Udayana, Bali, Indonesia \\ email: nikadek_sugiartini12@yahoo.co.id
}

\begin{abstract}
ABSTRAK
Penelitian ini bertujuan untuk mengetahui pengaruh likuiditas dan modal kerja terhadap profitabilitas. Rasio likuiditas pada penelitian ini diproksikan dengan current ratio, sedangkan modal kerja diproksikan dengan perputaran kas, perputaran piutang, dan perputaran persediaan. Profitabilitas sebagai variabel dependen diproksikan dengan ROA. Penelitian ini dilakukan pada perusahaan industri barang konsumsi yang terdaftar di Bursa Efek Indonesia pada tahun 2013-2017. Populasi pada penelitian ini adalah seluruh perusahaan sektor industri barang konsumsi yang terdaftar di BEI dengan total sejumlah 48 perusahaan. Pemilihan sampel penelitian menggunakan teknik purposive sampling, sehingga diperoleh sampel sebanyak 31 perusahaan. Penelitian ini menggunakan data sekunder berupa laporan keuangan perusahaan. Pengumpulan data dilakukan berdasarkan metode observasi nonperilaku dengan regresi linier berganda sebagai alat analisis. Berdasarkan hasil analisis, diperoleh bahwa perputaran kas dan perputaran piutang tidak berpengaruh terhadap profitabilitas. Variabel lainnya yaitu perputaran persediaan dan current ratio berpengaruh terhadap profitabilitas.
\end{abstract}

Kata Kunci: likuiditas, perputaran kas, perputaran piutang, perputaran persediaan, profitabilitas

\begin{abstract}
This study aims to determine the effect of liquidity and working capital on profitability. The liquidity ratio in this study is proxied by the current ratio, while working capital is proxied by cash turnover, accounts receivable turnover, and inventory turnover. This research was conducted on consumer goods industry companies listed on the Indonesia Stock Exchange in 2013-2017. The population in this study were all consumer goods industry companies listed on the Indonesia Stock Exchange with a total of 48 companies. The selection of research samples using purposive sampling technique, so as to obtain a sample of 31 companies. This research using secondary data in the form of company financial statements. Data collection is based on non-behavioral observation methods with multiple linear regression as an analysis tool. Based on the results of the analysis, it was found that cash turnover and accounts receivable turnover did not affect profitability. Other variables, namely inventory turnover and current ratio are affect profitability.

Keywords: liquidity, cash turnover, receivable turnover, inventory turnover, profitability
\end{abstract}




\section{PENDAHULUAN}

Pada umumnya, keberhasilan suatu perusahaan dalam menjalankan aktivitas usahanya seringkali dinilai berdasarkan tingkat laba yang diperoleh dalam periode waktu tertentu. Semakin tinggi laba, maka semakin mampu perusahaan bertahan, bertumbuh dan berkembang ditengah-tengah persaingan yang ada (Munawir, 2001:80). Kemampuan perusahaan dalam menghasilkan keuntungan (laba) dapat diketahui dengan melakukan perhitungan profitabilitas perusahaan tersebut. Oleh karena itu, perhitungan profitabilitas merupakan suatu hal yang mutlak untuk sebuah perusahaan (Handayani, Kristianto \& Astuti, 2016).

Sulindawati, Yuniarta, dan Purnamawati (2017:135) mendefinisikan profitabilitas merupakan rasio yang bertujuan untuk mengukur kemampuan perusahaan untuk memperoleh keuntungan dari penggunaan modalnya. Raharjaputra (2009:205) juga menyatakan bahwa rasio ini lebih diminati oleh para pemegang saham sebagai salah satu alat pembuat keputusan investasi karena berfungsi untuk mengukur besarnya kemampuan perusahaan dalam menciptakan tingkat perolehan keuntungan baik dalam bentuk laba perusahaan maupun nilai ekonomis atas penjualan, aset bersih perusahaan maupun modal sendiri.

Ukuran profitabilitas dalam penelitian ini diproksikan dengan return on asset (ROA). Menurut Brigham dan Houston (201:185) Return On Asset (ROA) merupakan ukuran profitabilitas yang memperhatikan jumlah sumber dana yang dibutuhkan untuk mendukung operasi atau kegiatan perusahaan. ROA mengukur efektivitas manajemen untuk menghasilkan laba dari aktiva perusahaan yang tersedia dan merupakan ukuran tingkat pengembalian yang paling tinggi. ROA dapat menunjukkan seberapa banyak hasil yang telah diperoleh perusahaan atas sumber daya modal yang ditanamkan perusahaan dan merupakan salah satu teknik yang bersifat menyeluruh serta lazim digunakan untuk mengukur tingkat efektifitas keseluruhan operasi perusahaan. Alasan lain dalam penggunaan ROA sebagai proksi dari profitabilitas dalam penelitian ini dikarenakan ROA mengukur besarnya efisiensi penggunaan atau pengelolaan modal secara menyeluruh dan sensitif terhadap hal-hal yang mempengaruhi keadaan perusahaan untuk menghasilkan laba (Marusya dan Magantar, 2016).

Besarnya pengaruh faktor-faktor yang mempengaruhi profitabilitas suatu perusahaan dapat diukur dengan beberapa rasio. Salah satu rasio tersebut adalah Current Ratio (Rasio Lancar), yang menunjukkan kemampuan perusahaan untuk melunasi kewajiban jangka pendeknya dengan menggunakan aktiva lancarnya (Wiagustini, 2014:86). Current ratio merupakan ukuran yang paling umum digunakan untuk mengetahui kesanggupan perusahaan dalam memenuhi kewajiban jangka pendeknya dengan seluruh aktiva lancar yang dimiliki. Alasan lain menggunakan current ratio sebagai proksi dari likuiditas dalam penelitian ini karena current ratio membandingkan keseluruhan aktiva lancar perusahaan terhadap utang lancar yang dimiliki, sehingga dapat menunjukkan efektifitas pengelolaan aktiva dalam operasional perusahaan. Horne dan Wachowicz (2012:166) mengemukakan bahwa likuiditas berbanding terbalik dengan profitabilitas, dengan kata lain meningkatkan likuiditas merupakan biaya dari menurunnya tingkat profitabilitas perusahaan. 
Beberapa bukti empiris juga membuktikan bahwa Current Ratio berpengaruh terhadap profitabilitas perusahaan menunjukkan hasil yang berbeda. Charitou, Lois, dan Santoso (2012) menemukan bahwa current ratio berpengaruh positif terhadap profitabilitas. Hal ini didukung oleh hasil temuan Ray (2014) dan Dalayeen (2017) bahwa current ratio berpengaruh positif terhadap profitabilitas perusahaan. Hasil temuan tersebut bertentangan dengan penelitian Ahmed, Awan, Safdar, Hasnain dan Kamran (2016) dan didukung oleh temuan Barua, Barua, \& Rana (2018) bahwa current ratio berpengaruh negatif terhadap profitabilitas perusahaan.

Menurut Tsagem, Aripin dan Ishak (2015), tinggi rendahnya tingkat profitabilitas yang dihasilkan dipengaruhi banyak faktor, salah satu faktornya adalah modal kerja seperti kas, piutang, serta persediaan. Modal kerja merupakan hal utama yang diperlukan perusahaan untuk membiayai kegiatan operasional perusahaan. Dalayeen (2017) menyatakan bahwa modal kerja merupakan modal yang tersedia untuk memenuhi operasi sehari-hari suatu perusahaan yang besarnya dapat tergantung pada jenis industri perusahaan tersebut. Naveen (2014) mengungkapkan manajemen modal kerja sangat berkaitan dengan pengelolaan aset lancar serta kewajiban lancar sedemikian rupa sehingga tingkat modal kerja yang optimal dapat dipertahankan. Manajemen modal kerja perusahaan yang optimal dapat dicapai oleh perusahaan dengan mengelola tradeoff antara profitabilitas dan likuiditas perusahaan tersebut (Sarbapriya, 2012).

Menurut Husnan dan Pudjiastuti (2012:107) kas adalah bentuk aktiva lancar yang paling likuid, sehingga bisa digunakan sesegera mungkin untuk memenuhi kewajiban finansial yang dimiliki perusahaan. Perputaran kas menunjukkan berapa lama kas akan terikat pada modal kerja hingga kembali lagi menjadi kas. Riyanto (2001:254) juga mengungkapkan bahwa perputaran kas yang semakin tinggi akan semakin baik, hal ini berarti semakin tinggi efisiensi penggunaan kas dalam perusahaan, maka perolehan keuntungan akan semakin besar. Hal ini didukung oleh penelitian Hoang (2015) yang menemukan bahwa perputaran kas (cash cycle) memiliki pengaruh yang positif terhadap profitabilitas. Hasil serupa juga ditemukan oleh Ayub (2015) dan Afrifa dan Padachi (2016) bahwa terdapat hubungan yang positif antara perputaran kas dengan profitabilitas. Berbeda dengan hasil temuan Ahmed et al. (2016) serta hasil temuan Singh dan Kumar (2017) yang menyatakan bahwa perputaran kas memiliki pengaruh negatif terhadap profitabilitas. Hal tersebut dikarenakan upaya perusahaan dalam meningkatkan laba adalah dengan menurunkan investasinya dalam aktiva lancar, selain itu perusahaan juga selalu memperhatikan pengeluaran operasional sehari-hari dan juga permintaan kreditur setiap saat.

Komponen modal kerja lainnya adalah piutang, yang muncul akibat adanya penjualan yang dilakukan secara kredit. Husnan dan Pudjiastuti (2012:117) mengungkapkan penjualan secara kredit merupakan salah satu upaya perusahaan untuk meningkatkan penjualan. Disamping itu, adanya piutang akan menimbulkan berbagai biaya bagi perusahaan, sehingga perlu dilakukan analisis dan pengelolaan untuk menilai manfaat piutang lebih besar ataukah lebih kecil dari biaya yang akan ditimbulkan. Hal ini sesuai dengan temuan Ayub (2015) yang menyatakan bahwa piutang memiliki hubungan positif terhadap profitabilitas. Hal ini serupa dengan hasil temuan Ray (2014) yang menemukan bahwa piutang perusahaan memiliki 
hubungan yang positif terhadap profitabilitas. Hasil dari penelitian itu bertentangan dengan penelitian Baidh (2013), Hoang (2015) dan Tran, Abbott, \& Yap (2017) yang menemukan bahwa perputaran piutang memiliki hubungan negatif terhadap profitabilitas. Hal tersebut dikarenakan perusahaan kurang ketat dalam menentukan kebijakan kredit, sehingga mengakibatkan profitabilitas perusahaan menurun.

Persediaan merupakan bagian utama dari modal kerja karena jumlahnya yang cukup besar pada suatu perusahaan. Jenis persediaan yang dimiliki suatu perusahaan sangat tergantung dari jenis perusahaan tersebut. Tingkat persediaan perusahaan berakibat pada perputaran persediaan yang dapat mempengaruhi tingkat profitabilitas perusahaan, sehingga tingkat persediaan perusahaan harus dikendalikan agar dapat mencapai tingkat profitabilitas yang maksimal (Wiagustini, 2014:168). Hal ini didukung oleh penelitian Ray (2014) dan Ayub (2015) yang menemukan bahwa perputaran persediaan memiliki hubungan yang positif terhadap profitabilitas perusahaan. Hasil penelitian tersebut bertentangan dengan penelitian yang dilakukan oleh Hoang (2015). Hal ini juga didukung oleh temuan Anarfi dan Boateng (2016), Dalayeen (2017) dan Tran et al. (2017) yang menyatakan perputaran persediaan berpengaruh negatif terhadap profitabilitas. Hal tersebut dikarenakan perusahaan tidak menetapkan pemasoknya dengan baik, sehingga jumlah persediaan kurang dapat dikendalikan oleh perusahaan.

Tabel 1.

Nilai Indeks Harga Saham Sektoral Tahun 2016-2017

\begin{tabular}{clrr}
\hline No. & \multicolumn{1}{c}{ Sektor } & \multicolumn{2}{c}{ Harga Saham (Rp) } \\
& & $\mathbf{2 0 1 6}$ & $\mathbf{2 0 1 7}$ \\
\hline 1. & Pertanian & $1.864,25$ & $1.616,31$ \\
2. & Pertambangan & $1.384,71$ & $1.539,99$ \\
3. & Industri Dasar & 538,19 & 689,22 \\
4. & Aneka Industri & $1.370,63$ & $1.381,18$ \\
5. & Industri Barang Konsumsi & $2.324,28$ & $2.861,39$ \\
6. & Properti dan Real Estate & 517,81 & 495,51 \\
7. & Infrastruktur dan Transportasi & $1.055,59$ & $1.183,71$ \\
8. & Keuangan & 811,89 & $1.140,84$ \\
9. & Perdagangan dan Investasi & 860,65 & 921,59 \\
10. & Manufaktur & $1.368,70$ & $1.640,18$ \\
\hline
\end{tabular}

Sumber : Bursa Efek Indonesia, 2018

Hasil penelitian yang belum konsisten ini mengindikasikan bahwa masih terdapat research gap, sehingga membuka peluang untuk dilakukan penelitian kembali mengenai pengaruh likuiditas dan modal kerja terhadap profitabilitas. Penelitian ini dilakukan pada perusahaan sektor Industri Barang Konsumsi (consumer goods) yang termasuk dalam golongan perusahaan manufaktur yang terdaftar di Bursa Efek Indonesia. Industri barang konsumsi adalah perusahaan yang bergerak dalam bidang produksi dan penyediaan barang-barang kebutuhan hidup manusia.

Penelitian ini menyasar perusahaan yang bergerak dalam sektor industri barang konsumsi sebagai objek penelitian karena sektor ini memiliki harga saham tertinggi dibandingkan dengan sektor lainnya. Hal tersebut karena perusahaan pada 
sektor barang konsumsi memiliki prospek yang mendukung di masa mendatang karena barang-barang konsumsi ini selalu diperlukan untuk memenuhi kebutuhan hidup manusia. Dengan demikian tentunya akan semakin meningkat pula profitabilitas perusahaan tersebut.

Pada Tabel 2. yang dikutip dari laporan keuangan tahunan perusahaan industri barang konsumsi yang terdaftar di Bursa Efek Indonesia, menunjukkan bahwa tingkat profitabilitas yang diukur dengan ROA pada perusahaan barang konsumsi pada tahun 2014 hingga tahun 2016 mengalami fluktuasi. Seperti yang dijelaskan pada ikhtiar laporan keuangan tahunan PT. Gudang Garam Tbk, profitabilitas perusahaan pada tahun 2014 sebesar 9,27\% mengalami kenaikan di tahun 2015 menjadi 10,16\%. Kenaikan tingkat profitablitas pada PT. Gudang Garam Tbk ini dikarenakan PT. Gudang Garam Tbk terus melakukan perluasan ketersediaan produk dan pangsa pasar dengan kapasitas produksi yang mencukupi untuk memenuhi permintaan pasar sehingga pendapatan perusahaan meningkat sebesar 7,9\% menjadi Rp 70,4 triliun. Kemampuan perusahaan dalam menekan biaya yang harus dikeluarkan dan meningkatkan penjualan menyebabkan meningkatnya profitabilitas perusahaan. Perputaran persediaan barang menjadi lebih cepat karena perusahaan dapat mengontrol biaya yang dikeluarkan sehingga dapat meningkatkan profitabilitas.

Berbeda halnya dengan PT. Indofood Sukses Makmur Tbk yang mengalami penurunan pada tingkat profitabilitasnya dari tahun 2014 sebesar 5,99\% menjadi $4,04 \%$ di tahun 2015. Melemahnya perekonomian di negara-negara berkembang menjadi salah satu penyebab menurunnya tingkat profitabilitas perusahaan. Tingkat kepercayaan dan daya beli konsumen yang melemah mengakibatkan konsumsi rumah tangga mengalami perlambatan, sehingga permintaan terhadap produkproduk barang konsumsi cenderung stagnan. Menurunnya tingkat permintaan mengakibatkan penjualan PT. Indofood Sukses Makmur Tbk juga mengalami penurunan yang berakibat pula pada menurunnya tingkat profitabilitas perusahaan. Penjualan menjadi salah satu indikator yang penting untuk meningkatkan profitabilitas perusahaan, selain menekan biaya yang harus dikeluarkan oleh perusahaan.

Berdasarkan uraian di atas, dapat digambarkan bahwa tingkat profitabilitas suatu perusahaan tidak selalu dapat dipertahankan. Maka penelitian ini mencoba untuk meneliti seberapa besar pengaruh manajemen modal kerja terhadap tingkat profitabilitas. Adanya perbedaan hasil penelitian terdahulu mengenai pengaruh manajemen modal terhadap tingkat profitabilitas perusahaan, juga menjadi suatu celah yang memperkuat penelitian ini dilakukan dan diproyeksikan pada perusahaan industri barang konsumsi yang terdaftar di Bursa Efek Indonesia.

Profitabilitas adalah kemampuan perusahaan memperoleh laba dalam hubungannya dengan penjualan, total aktiva maupun modal sendiri. Dengan demikian, bagi investor yang berorientasi pada investasi jangka panjang, akan sangat berkepentingan dengan analisis profitabilitas ini karena akan melihat besarnya keuntungan yang akan diterima nantinya (Sartono, 2001:122). Menurut Wiagustini (2014:86) profitabilitas menunjukkan kemampuan perusahaan memperoleh laba atau ukuran efektivitas pengelolaan manajemen perusahaan. 
Tabel 2.

Tingkat Profitabilitas pada Perusahaan Sektor Industri Barang Konsumsi yang terdaftar di Bursa Efek Indonesia Tahun 2014-2016.

\begin{tabular}{|c|c|c|c|c|c|}
\hline \multirow[t]{2}{*}{ No } & \multirow[t]{2}{*}{ Kode } & \multirow[t]{2}{*}{ Nama Perusahaan } & \multicolumn{3}{|c|}{ ROA (\%) } \\
\hline & & & 2014 & 2015 & 2016 \\
\hline 1 & ADES & Akasha Wira International Tbk. & 6.14 & 5.03 & 7.29 \\
\hline 2 & AISA & Tiga Pilar Sejahtera Food Tbk. & 5.13 & 4.12 & 7.77 \\
\hline 3 & ALTO & Tri Banyan Tirta Tbk. & -0.82 & -2.06 & -2.27 \\
\hline 4 & BTEK & Bumi Teknokultura Unggul Tbk & -0.73 & 0.05 & 0.05 \\
\hline 5 & BUDI & Budi Starch \& Sweetener Tbk. & 1.15 & 0.65 & 1.32 \\
\hline 6 & CEKA & Wilmar Cahaya Indonesia Tbk. & 3.19 & 7.17 & 17.51 \\
\hline 7 & DLTA & Delta Djakarta Tbk. & 29.04 & 18.50 & 21.25 \\
\hline 8 & DVLA & Darya-Varia Laboratoria Tbk. & 6.55 & 7.84 & 9.93 \\
\hline 9 & GGRM & Gudang Garam Tbk. & 9.27 & 10.16 & 10.60 \\
\hline 10 & HMSP & H.M. Sampoerna Tbk. & 35.87 & 27.26 & 30.02 \\
\hline 11 & ICBP & Indofood CBP Sukses Makmur Tbk & 10.16 & 11.01 & 12.56 \\
\hline 12 & IIKP & Inti Agri Resources Tbk & -3.38 & -4.86 & -7.55 \\
\hline 13 & INAF & Indofarma Tbk. & 0.09 & 0.43 & -1.26 \\
\hline 14 & INDF & Indofood Sukses Makmur Tbk. & 5.99 & 4.04 & 6.41 \\
\hline 15 & KAEF & Kimia Farma Tbk. & 7.97 & 7.82 & 5.89 \\
\hline 16 & KICI & Kedaung Indah Can Tbk & 4.86 & - 9.71 & 0.26 \\
\hline 17 & KLBF & Kalbe Farma Tbk. & 17.07 & 15.02 & 15.44 \\
\hline 18 & LMPI & Langgeng Makmur Industri Tbk. & 0.21 & 0.50 & 0.86 \\
\hline 19 & MBTO & Martina Berto Tbk. & 0.47 & -2.17 & 1.24 \\
\hline 20 & MERK & Merck Tbk. & 25.32 & 22.22 & 20.68 \\
\hline 21 & MLBI & Multi Bintang Indonesia Tbk. & 35.63 & 23.65 & 43.17 \\
\hline 22 & MRAT & Mustika Ratu Tbk. & 1.48 & 0.21 & -1.15 \\
\hline 23 & MYOR & Mayora Indah Tbk. & 3.98 & 11.02 & 10.75 \\
\hline 24 & PSDN & Prasidha Aneka Niaga Tbk & -4.54 & -6.87 & -5.61 \\
\hline 25 & PYFA & Pyridam Farma Tbk & 1.54 & 1.93 & 3.08 \\
\hline 26 & RMBA & Bentoel Internasional Investam & -22.23 & -12.94 & -15.48 \\
\hline 27 & ROTI & Nippon Indosari Corpindo Tbk. & 8.80 & 10.00 & 9.58 \\
\hline 28 & SKBM & Sekar Bumi Tbk. & 13.72 & 5.25 & 2.25 \\
\hline 29 & SKLT & Sekar Laut Tbk. & 4.97 & 5.32 & 3.63 \\
\hline 30 & STTP & Siantar Top Tbk. & 7.26 & 9.67 & 7.45 \\
\hline 31 & TCID & Mandom Indonesia $\mathrm{Tb}$ & 9.41 & 26.15 & 7.42 \\
\hline 32 & TSPC & Tempo Scan Pacific Tbk. & 10.45 & 8.42 & 8.28 \\
\hline 33 & ULTJ & Ultra Jaya Milk Industry \& Tra & 9.71 & 14.78 & 16.74 \\
\hline 34 & UNVR & Unilever Indonesia Tbk. & 40.18 & 37.20 & 38.16 \\
\hline 35 & WIIM & Wismilak Inti Makmur Tbk. & 8.43 & 9.76 & 7.85 \\
\hline
\end{tabular}

Return On Asset (ROA) merupakan ukuran profitabilitas yang memperhatikan jumlah sumber dana yang dibutuhkan untuk mendukung operasi atau kegiatan perusahaan. ROA mengukur efektivitas manajemen dalam menghasilkan laba dari aktiva yang tersedia dan merupakan ukuran tingkat pengembalian yang paling tinggi. ROA ini dapat menggambarkan profitabilitas perusahaan dengan membandingkan laba bersih dan total aset yang dimiliki perusahaan (Brigham dan Houston, 201:185). Fahmi (2016:82) menyatakan bahwa ROA dapat dihitung menggunakan rumus sebagai berikut:

$$
\text { Return On Asset }(\mathrm{ROA})=\frac{\text { Laba bersih Setelah Pajak }}{\text { Total Asset }} \text { X 100\%. }
$$


Besarnya pengaruh faktor-faktor yang mempengaruhi profitabilitas suatu perusahaan dapat diketahui dari angka-angka rasio keuangan lainnya, diantaranya adalah Rasio Likuiditas. Rasio Likuiditas digunakan untuk mengukur kemampuan perusahaan untuk memenuhi liabilitas jangka pendeknya. Rasio ini membandingkan membandingkan liabilitas jangka pendek dengan sumber daya jangka pendek (atau lancar) yang tersedia untuk memenuhi liabilitas tersebut. Horne dan Wachowicz (2012:166-176) menyatakan Current Ratio merupakan rasio likuiditas yang menunjukkan kemampuan perusahaan untuk membayar liabilitas jangka pendeknya dengan menggunakan aset lancarnya. Semakin tinggi rasio lancar, maka akan semakin besar kemampuan perusahaan untuk membayar tagihannya. Husnan (1998:440-447) menjelaskan bahwa pemeliharaan aktiva likuid dapat dibenarkan apabila pasar modal tidak sempurna, hal ini berarti semakin tinggi tingkat current ratio maka akan memperkecil risiko terjadinya kebangkrutan karena likuiditas yang tersedia mencukupi untuk menutupi kebangkrutan tersebut. Rasio Lancar dapat dihitung menggunakan rumus sebagai berikut:

$$
\text { Current Ratio }\left(\text { Rasio Lancar) }=\frac{\text { Aktiva Lancar }}{\text { Utang Lancar }} \times 100 \% \ldots \ldots \ldots \ldots \ldots . . . .(2)\right.
$$

Charitou, Lois, dan Santoso (2012) dalam penelitiannya menemukan bahwa current ratio berpengaruh positif terhadap profitabilitas. Hal ini didukung oleh hasil temuan Ambarwati, Yuniarta, dan Sinarwati (2015), serta didukung pula oleh hasil penelitian Ray (2014) dan Dalayeen (2017), bahwa current ratio berpengaruh positif terhadap profitabilitas perusahaan. Dengan demikian, maka dapat dirumuskan hipotesis sebagai berikut.

$\mathrm{H}_{1}$ : Current ratio berpengaruh positif terhadap profitabilitas.

Modal kerja adalah investasi sebuah perusahaan pada aktiva-aktiva jangka pendek seperti kas, sekuritas, persediaan, dan piutang (Fahmi, 2016:100). Fahmi (2016:100) juga mengungkapkan bahwa ketika penempatan dana terlalu besar pada salah satu akun, atau sebaliknya terlalu kecil, maka dampaknya akan mengganggu stabilitas keuangan perusahaan. Jika kas yang dimiliki perusahaan terlalu besar maka perusahaan dikatakan likuid, namun hal tersebut memposisikan bahwa perusahaan tidak optimal dalam menggunakan dana yang dimilikinya. Dalam artian, memungkinkan terjadinya penumpukan dana yang menganggur (idle money) dalam bentuk kas secara tidak terkontrol. Modal kerja yang berlebihan sering disebut overliquid, terutama dalam bentuk kas dan surat berharga yang dapat merugikan perusahaan, karena akan ada dana yang tidak digunakan secara efektif sehingga tidak mampu meningkatkan profitabilitas perusahaan tersebut.

Manajemen modal kerja yang efektif sangat dibutuhkan untuk pertumbuhan perusahaan dalam jangka panjang, karena jika perusahaan kekurangan modal kerja untuk memperluas penjualan dan meningkatkan produksinya, maka perusahaan kemungkinan akan kehilangan pendapatan dan keuntungannya (Sartono, 2001:385). Kas merupakan elemen modal kerja yang memiliki tingkat likuiditas paling tinggi dibandingkan dengan aset lainnya. Hal ini berarti bahwa semakin besar jumlah kas yang dimiliki oleh perusahaan maka semakin tinggi pula tingkat 
likuiditasnya. Jumlah kas yang terlalu kecil juga dapat mengakibatkan perusahaan mengalami kesulitan dalam kegiatan operasional sehari-hari misalnya terganggunya pembayaran hutang jangka pendek, pembayaran gaji karyawan dan sebagainya (Wiagustini, 2014:139).

Menurut Riyanto (2001:143) yang mengutip pernyataan Guthmann menjelaskan bahwa jumlah kas yang dimilik perusahaan hendaknya minimal antara 5\% hingga 10\% dari jumlah aktiva lancar. Jumlah kas juga dapat dihubungkan dengan jumlah penjualannya. Perbandingan antara penjualan dengan jumlah rata-rata kas dapat menggambarkan tingkat perputaran kas (cash turnover) yang merupakan kemampuan kas dalam menghasilkan pendapatan sehingga dapat dilihat berapa kali uang kas berputar dalam satu periode tertentu. Untuk menghitung perputaran kas dapat digunakan rumus sebagai berikut:

$$
\text { Perputaran Kas }=\quad \frac{\text { penjualan bersih }}{\text { rata-rata kas }}(\text { kali) }
$$

Semakin tinggi perputaran kas yang terjadi maka akan semakin baik, karena semakin tinggi tingkat efisiensi penggunaan kas dalam perusahaan tersebut. Hal ini berarti semakin tinggi efisiensi penggunaan kasnya maka keuntungan yang akan diperoleh semakin besar (Riyanto, 2001:62). Tetapi cash turnover yang terlalu tinggi mengartikan bahwa kas yang tersedia terlalu kecil untuk volume penjualan tersebut. Penelitian Hoang (2015) juga mendukung hal tersebut, yang menemukan bahwa perputaran kas (cash cycle) memiliki pengaruh yang positif terhadap profitabilitas. Hasil yang sama juga ditemukan oleh Ayub (2015) dan Afrifa dan Padachi (2016) bahwa terdapat hubungan yang positif antara perputaran kas dengan profitabilitas. Dengan demikian, maka dapat dirumuskan hipotesis sebagai berikut.

$\mathrm{H}_{2}$ : Perputaran kas berpengaruh positif terhadap profitabilitas.

Menurut Jusup (2005:52) mengungkapkan bahwa pada umumnya, piutang timbul karena perusahaan melakukan transaksi penjualan secara kredit. Dengan kata lain, piutang merupakan tagihan kepada pihak lain dalam bentuk uang atau barang yang timbul dari adanya penjualan secara kredit oleh perusahaan. Hubungan antara penjualan kredit dengan piutang yang dimiliki oleh perusahaan menggambarkan perputaran piutang. Semakin cepat periode perputaran piutang yang dihasilkan, menunjukkan semakin cepat pula penjualan kredit dapat dikembalikan menjadi kas (Sartono, 2001:119). Perputaran piutang dapat dihitung dengan cara membagi penjualan dengan rata-rata piutang, yang dapat dirumuskan sebagai berikut:

$$
\text { Perputaran Piutang }=\frac{\text { penjualan kredit bersih }}{\text { rata-rata piutang }}(\text { kali) }
$$

Jika perputaran piutang semakin cepat, maka profitabilitas yang diperoleh akan semakin tinggi (Martono dan Hajrito, 2003:50). Hal ini sesuai dengan temuan Ayub (2015) yang menyatakan bahwa piutang memiliki hubungan positif terhadap profitabilitas. Hasil temuan tersebut juga didukung oleh temuan Utami dan Dewi (2016) serta Dwiyanthi dan Sudiartha (2017) yang menunjukkan bahwa perputaran 
piutang memiliki pengaruh positif terhadap profitabilitas perusahaan. Dengan demikian, maka dapat dirumuskan hipotesis sebagai berikut.

$\mathrm{H}_{3}$ : Perputaran piutang berpengaruh positif terhadap profitabilitas.

Menurut Sartono (2001:443) persediaan merupakan faktor penting dalam menentukan kelancaran operasional perusahaan, sehingga jumlahnya cukup besar dalam suatu perusahaan. Jenis persediaan yang ada dalam perusahaan akan tergantung pada jenis perusahaan yang dijalankan. Wiagustini (2014:168) mengungkapkan, apabila persediaan dalam terlalu kecil maka besar kemungkinan kegiatan operasional mengalami penundaan atau perusahaan beroperasi dalam kapasitas yang rendah. Efisiensi persediaan dapat diukur jika diketahui perputaran persediaan yang terjadi. Hal ini dapat diketahui dengan membandingkan harga pokok penjualan (HPP) dengan nilai rata-rata persediaan yang dimiliki oleh perusahaan yang dapat dirumuskan sebagai berikut.

$$
\text { Perputaran Persediaan }=\frac{\text { harga pokok penjualan }}{\text { rata-rata persediaan }}(\text { kali })
$$

Tingkat persediaan perusahaan berakibat pada perputaran persediaan yang dapat mempengaruhi tingkat profitabilitas perusahaan, sehingga harus dikendalikan agar efisien (Wiagustini, 2014:168). Tingkat perputaran persediaan yang semakin tinggi menggambarkan jumlah modal kerja yang dibutuhkan semakin rendah (Sartono, 2001:119). Hal ini didukung oleh penelitian Ray (2014), Ayub (2015) serta Dwiyanthi dan Sudiartha (2017) yang menemukan bahwa perputaran persediaan memiliki hubungan yang positif terhadap profitabilitas. Dengan demikian, maka dapat dirumuskan hipotesis sebagai berikut.

$\mathrm{H}_{4}$ : Perputaran persediaan berpengaruh positif terhadap profitabilitas.

\section{METODE PENELITIAN}

Penelitian ini menggunakan metode kuantitatif dengan bentuk asosiatif yang bertujuan untuk mengetahui dan menjelaskan hubungan antara dua variabel atau lebih (Sugiyono, 2016). Penelitian ini dilakukan pada perusahaan Industri Barang Konsumsi yang terdaftar di Bursa Efek Indonesia pada tahun 2013-2017. Informasi dapat diperoleh dengan mengakses website www.idx.co.id yang menyediakan data mengenai laporan keuangan dan laporan tahunan perusahaan barang konsumsi yang terdaftar di Bursa Efek Indonesia tahun 2013-2017. Obyek pada penelitian ini adalah Current Ratio, Perputaran Kas, Perputaran Piutang, dan Perputaran Persediaan yang dapat dilihat pada laporan keuangan yang menampilkan data mengenai keadaan finansial pada perusahaan barang konsumsi yang terdaftar di Bursa Efek Indonesia tahun 2013-2017.

Variabel Dependen (terikat) adalah variabel yang dipengaruhi atau yang menjadi akibat karena adanya variabel bebas (Sugiyono, 2016:97). Dalam penelitian ini variabel dependen (Y) adalah profitabilitas perusahaan barang konsumsi yang diproksikan dengan ROA, yaitu laba bersih dari kegiatan operasional perusahaan setelah pajak dibagi dengan jumlah keseluruhan dari aset 
yang dimiliki oleh perusahaan yang bersangkutan. Variabel Independen (bebas) adalah variabel yang menjadi sebab perubahannya atau yang mempengaruhi variabel dependen atau terikat (Sugiyono, 2014:96). Variabel independen (X) dalam penelitian ini yaitu Current Ratio $\left(\mathrm{X}_{1}\right)$, Perputaran Kas $\left(\mathrm{X}_{2}\right)$, Perputaran Piutang $\left(\mathrm{X}_{3}\right)$, dan Perputaran Persediaan $\left(\mathrm{X}_{4}\right)$.

Pengumpulan data dalam penelitian ini menggunakan metode observasi nonperilaku, yaitu dengan membaca, mengumpulkan, mencatat data-data dan informasi yang diperlukan (Hartono, 2013:111). Observasi dilakukan terhadap data laporan keuangan perusahaan Barang Konsumsi yang terdaftar di Bursa Efek Indonesia (BEI) tahun 2013 - 2017 yang dipublikasikan melalui website www.idx.co.id.

Data kuantitatif adalah data dalam bentuk angka yang dapat dinyatakan dan diukur dengan satuan hitung atau kualitatif yang diangkakan (Sugiyono, 2016:28). Data yang digunakan dalam penelitian ini adalah data yang bersifat kuantitatif yang berhubungan dengan tingkat penjualan, piutang, kas, serta ROA yang dapat ditemukan dalam laporan keuangan perusahaan barang konsumsi selama lima tahun yaitu dari tahun 2013 - 2017 yang terdaftar di Bursa Efek Indonesia (BEI). Berdasarkan sumbernya, penelitian ini menggunakan sumber data sekunder yang merupakan data-data yang ada telah dikumpulkan oleh pihak lain terlebih dahulu atau melalui dokumen, yang kemudian digunakan oleh peneliti sebagai pertimbangan dalam penelitiannya.

\section{Tabel 3.}

Proses Penentuan Sampel Penelitian

\begin{tabular}{clc}
\hline No. & \multicolumn{1}{c}{ Keterangan Kriteria } & \multicolumn{1}{c}{$\begin{array}{c}\text { Jumlah } \\
\text { Perusahaan }\end{array}$} \\
\hline 1. & $\begin{array}{l}\text { Perusahaan sektor Industri Barang Konsumsi yang terdaftar di Bursa } \\
\text { Efek Indonesia per September 2018 }\end{array}$ & 48 \\
2. $\begin{array}{l}\text { Perusahaan Barang Konsumsi yang tidak terdaftar di Bursa Efek } \\
\text { Indonesia berturut-turut pada tahun 2013-2017 }\end{array}$ & $(12)$ \\
3. $\begin{array}{l}\text { Perusahaan Barang Konsumsi yang tidak mempublikasikan laporan } \\
\text { keuangan tahunan di Bursa Efek Indonesia secara berturut-turut pada } \\
\text { tahun 2013-2017. } \\
\text { Total Perusahaan sebagai Sampel }\end{array}$ & (5) \\
\hline Sumber Bursa Efek Indonesia, 2018
\end{tabular}

Populasi dalam penelitian ini adalah seluruh Perusahaan Barang Konsumsi yang terdaftar yang terdaftar di Bursa Efek Indonesia (BEI) dengan jumlah total sebanyak 48 perusahaan. Teknik pengambilan sampel yang digunakan dalam penelitian ini adalah purposive sampling yang merupakan teknik penentuan sampel dengan pertimbangan tertentu (Sugiyono, 2016:156). Perusahaan yang terpilh menjadi sampel pada penelitian ini dapat diuraikan pada Tabel 3.

Data yang dikumpulkan dalam penelitian ini akan dianalisis dengan teknik analisis regresi linier berganda, untuk mengetahui ketergantungan suatu variabel terikat dengan satu atau lebih variabel bebas. Analisis ini juga dapat menduga arah dari hubungan tersebut serta mengukur derajat keeratan hubungan antara satu variabel terikat dengan satu variabel bebas. Dalam analisis, peneliti dibantu dengan 
program komputer Statitical Package of Social Science (SPSS). Adapun bentuk umum dari persamaan regresi linier berganda menurut Utama (2016:77) sebagai berikut:

$$
Y=\beta_{0}+\beta_{1} X_{1}+\beta_{2} X_{2}+\beta_{3} X_{3}+\beta_{4} X_{4}+e .
$$

Dimana :

$\mathrm{Y} \quad=$ Profitabilitas (Return on Assets)

$\beta_{0} \quad=$ Konstanta

$\beta_{1,2,3,4}=$ Koefisien regresi dari $X_{1}, X_{2}, X_{3}, X_{4}$

$\mathrm{X}_{1} \quad=$ Current Ratio

$\mathrm{X}_{2} \quad=$ Tingkat Perputaran Kas

$\mathrm{X}_{3} \quad=$ Tingkat Perputaran Piutang

$\mathrm{X}_{4} \quad=$ Tingkat Perputaran Persediaan

$e \quad=$ Variabel pengganggu (residual error) yang mewakili faktor lain berpengaruh terhadap Y namun tidak dimasukkan dalam model

Sebelum dianalisis dengan regresi linier berganda, maka dilakukan pengujian asumsi klasik yang meliputi uji normalitas, uji autokorelasi, uji multikolinearitas, dan uji heteroskedastisitas terlebih dahulu untuk mengetahui kelayakan sebaran data penelitian. Uji kelayakan model (uji F) dan uji regresi parsial (t-test) selanjutnya dilakukan setelah dilakukan uji asumsi klasik. Uji F pada dasarnya digunakan untuk mengetahui apakah seluruh variabel independen yang digunakan dalam model regresi berpengaruh secara simultan terhadap variabel dependen (Ghozali, 2016:96).

\section{HASIL DAN PEMBAHASAN}

Statistik deskriptif memberikan gambaran atau deskripsi suatu data yang dilihat dari nilai rata-rata (mean), standar deviasi, nilai tertinggi, dan nilai terendah dari seluruh variabel yang diteliti. Berdasarkan Tabel 4. terdapat berbagai informasi yang memberikan gambaran atau deskripsi dari variabel yang digunakan. Hasil olah data dengan bantuan software menunjukkan banyaknya pengamatan yang dilakukan adalah 125 (n).

Tabel 4.

Hasil Analisis Statistik Deskriptif

\begin{tabular}{lrrrrr}
\hline Keterangan & \multicolumn{1}{c}{$\begin{array}{c}\text { Current } \\
\text { Ratio }\end{array}$} & $\begin{array}{c}\text { Perputaran } \\
\text { Kas }\end{array}$ & $\begin{array}{c}\text { Perputaran } \\
\text { Piutang }\end{array}$ & $\begin{array}{c}\text { Perputaran } \\
\text { Persediaan }\end{array}$ & ROA \\
\hline Valid N & 125 & 125 & 125 & 125 & 125 \\
Minimum & 12.02 & 0.34 & 1.65 & 1.44 & -20.80 \\
Maximum & 540.00 & 261.31 & 45.39 & 49.12 & 25.62 \\
Mean & 215.7732 & 26.5472 & 12.2069 & 5.8133 & 5.5662 \\
Std. & 100.92718 & 38.12113 & 9.33318 & 6.09354 & 6.94706 \\
Deviation & & & & & \\
\hline
\end{tabular}

Sumber: Output SPSS, 2018.

Untuk menguji apakah distribusi data yang digunakan normal atau tidak, dapat dilakukan dengan Uji Kolmogorov-Smirnov. Persyaratannya adalah apabila 
Asymp, Sig. (2 tailed) lebih dari 0,05 (Asymp, Sig. (2 tailed) > 5\%), maka dapat dikatakan data telah terdistribusi normal (Utama, 2016:101). Tabel 5 menunjukkan bahwa Asymp. Sig. (2-tailed) sebesar 0.058. Hasil tersebut mengindikasikan bahwa model persamaan regresi dalam penelitian ini berdistribusi normal karena nilai Asymp. Sig. (2-tailed) 0.058 lebih besar dari nilai alpha 0.05 .

Tabel 5.

Hasil Uji Normalitas Kolmogorov-Smirnov

\begin{tabular}{llr}
\hline \multicolumn{2}{c}{ One-Sample Kolmogorov-Smirnov Test } & Unstandardized Residual \\
\hline $\mathrm{N}$ & & 125 \\
Normal Parameters ${ }^{\mathrm{a}, \mathrm{b}}$ & Mean & $0 \mathrm{E}-7$ \\
& Std. Deviation & 6.07461943 \\
Most Extreme Differences & Absolute & .119 \\
& Positive & .119 \\
& Negative & -.117 \\
Kolmogorov-Smirnov Z & & 1.332 \\
Asymp. Sig. (2-tailed) & & .058 \\
\hline \multicolumn{2}{c}{ Sumber: Output SPSS, 2018. }
\end{tabular}

Uji autokorelasi dapat dilakukan dengan Uji Durbin-Waston $\left(D_{w}-\right.$ test $)$ atau $\mathrm{d}$ statistik terhadap variabel pengganggu (disturbance error term). Bila angka $\mathrm{D}_{\mathrm{w}}$ berada diantara $\mathrm{D}_{\mathrm{u}}<\mathrm{D}_{\mathrm{w}}<4-\mathrm{D}_{\mathrm{u}}$ berarti tidak terjadi gejala autokorelasi (Utama, 2016:105).

Tabel 6.

Hasil Uji Autokorelasi

\begin{tabular}{cccccr}
\hline Model & $\mathbf{R}$ & $\begin{array}{c}\text { R } \\
\text { Square }\end{array}$ & $\begin{array}{c}\text { Adjusted R } \\
\text { Square }\end{array}$ & $\begin{array}{c}\text { Std. Error of the } \\
\text { Estimate }\end{array}$ & $\begin{array}{c}\text { Durbin- } \\
\text { Watson }\end{array}$ \\
\hline 1 & $.485^{\text {a }}$ & .235 & .210 & 6.17503 & 1.803 \\
\hline \multicolumn{2}{l}{ Sumber $:$ Output SPSS, 2018.} & & &
\end{tabular}

Tabel 6. menunjukkan bahwa nilai Durbin-Watson sebesar 1.803. Nilai ini akan dibandingkan dengan nilai tabel dengan menggunakan tingkat signifikansi 5\%, jumlah sampel 125 (n) dan jumlah variabel independen $4(\mathrm{k}=4)$, maka nilai pada tabel Durbin-Watson adalah sebesar 1.775. Nilai DW 1.803 lebih besar dari batas atas $(\mathrm{du})$ yaitu 1.775 dan kurang dari $4-\mathrm{du}(4-1.7745=2.228$, sehingga dapat disimpulkan bahwa tidak terdapat autokorelasi.

Untuk mendeteksi ada atau tidaknya korelasi antar semua variabel bebas dapat dilihat dari nilai tolerance dan nilai variance inflation factor (VIF). Jika nilai tolerance lebih dari 10 persen atau VIF kurang dari 10, maka dikatakan tidak ada multikolinearitas.

Tabel 7.

Ringkasan Hasil Uji Multikolinearitas

\begin{tabular}{lcc}
\hline \multicolumn{1}{c}{ Variabel } & Tolerance & VIF \\
\hline Current Ratio & 0.917 & 1.091 \\
Perputaran Kas & 0.861 & 1.162 \\
Perputaran Piutang & 0.887 & 1.127 \\
Perputaran Persediaan & 0.946 & 1.057 \\
\hline \multicolumn{1}{c}{ Sumber : Output SPSS, 2018. } & &
\end{tabular}


Tabel 7. menunjukkan nilai tolerance dan VIF dari variabel Current Ratio, Perputaran Kas, Perputaran Piutang, dan Perputaran Persediaan. Nilai tolerance masing-masing variabel lebih dari 0.10 dan nilai VIF untuk setiap variabel kurang dari 10, sehingga dapat disimpulkan bahwa model persamaan regresi dalam penelitian ini bebas dari multikolinearitas.

Tabel 8.

Hasil Uji Heteroskedastisitas

\begin{tabular}{|c|c|c|c|c|c|}
\hline \multirow[t]{2}{*}{ Model } & \multicolumn{2}{|c|}{$\begin{array}{l}\text { Unstandardized } \\
\text { Coefficients }\end{array}$} & \multirow{2}{*}{$\begin{array}{c}\text { Standardized } \\
\text { Coefficients } \\
\text { Beta }\end{array}$} & \multirow[t]{2}{*}{$t$} & \multirow[t]{2}{*}{ Sig. } \\
\hline & B & Std. Error & & & \\
\hline (Constant) & 2.362 & 1.210 & & 1.952 & .053 \\
\hline $\begin{array}{l}\text { Perputaran } \\
\text { Kas }\end{array}$ & -.004 & .011 & -.035 & -.364 & .716 \\
\hline $\begin{array}{l}\text { Perputaran } \\
\text { Piutang }\end{array}$ & .058 & .043 & .129 & 1.368 & .174 \\
\hline $\begin{array}{l}\text { Perputaran } \\
\text { Persediaan }\end{array}$ & -.032 & .063 & -.046 & -.507 & .613 \\
\hline Current Ratio & .007 & .004 & .175 & 1.879 & .063 \\
\hline
\end{tabular}

Uji heteroskedastisitas dapat dilakukan dengan Uji Glejser, yaitu dengan melihat nilai signifikansi di atas tingkat $\alpha=5 \%$, sehingga dapat disimpulkan bahwa model regresi tidak mengandung adanya Heteroskedastisitas (Utama, 2016:112113). Tabel 8 menunjukkan bahwa nilai signifikansi dari variabel current ratio $\left(\mathrm{X}_{1}\right)$ tingkat perputaran kas $\left(\mathrm{X}_{2}\right)$, tingkat perputaran piutang $\left(\mathrm{X}_{3}\right)$, tingkat perputaran persediaan $\left(\mathrm{X}_{4}\right)$, masing-masing adalah sebesar $0.716,0.174,0.613$, dan 0.063 . Nilai signifikansi masing-masing variabel independen tersebut lebih besar dari alpha 0.05 , yang mengindikasikan bahwa tidak terdapat pengaruh antara variabel bebas terhadap absolute residual sehingga dapat disimpulkan bahwa model regresi tidak mengandung gejala heteroskedastisitas.

Tabel 9. menunjukkan nilai koefisien determinasi $\left(\mathrm{R}^{2}\right)$ sebesar 0,235 hal ini berarti bahwa $23,5 \%$ variasi (naik turunnya) ROA dipengaruhi oleh variabel perputaran kas, perputaran piutang perputaran persediaan, dan current ratio. Sisanya sebesar $76,5 \%$ dipengaruhi oleh variabel lain yang tidak dimasukkan ke dalam model regresi. Tabel 9 juga menunjukkan hasil uji ANOVA atau F test, bahwa diperoleh nilai $F_{\text {hitung }}$ sebesar 9,236 dengan signifikansi 0.000, sedangkan besarnya $F_{\text {tabel }}\left(\mathrm{F}_{0.05(4)(120)}\right)=2.45$. Berdasarkan hasil uji tersebut diketahui bahwa $F_{\text {hitung }}(9,236)>F_{\text {tabel }}(2,45)$ dan nilai signifikansi $0.000<0.05$, sehingga dapat disimpulkan bahwa model regresi dapat digunakan untuk memprediksi ROA atau dapat dikatakan bahwa Perputaran Kas, Perputaran Piutang, Perputaran Persediaan, dan Current Ratio secara bersama-sama berpengaruh terhadap ROA.

Berdasarkan Tabel 9. yang menyajikan hasil analisis regresi linier berganda, diperoleh persamaan regresinya sebagai berikut:

$\mathrm{Y}=\beta_{0}+\beta_{1} \mathrm{X}_{1}+\beta_{2} \mathrm{X}_{2}+\beta_{3} \mathrm{X}_{3}+\beta_{4} \mathrm{X}_{4}+e$

$\mathrm{Y}=-4.164+0.034 \mathrm{X}_{1}+0.015 \mathrm{X}_{2}+0.068 \mathrm{X}_{3}+0.199 \mathrm{X}_{4}$ 
$\beta_{0}=-4,164$, secara statistik hasil regresi menunjukkan bahwa, apabila perputaran kas, perputaran piutang, perputaran persediaan, dan current ratio dianggap konstan (nol), maka nilai variabel ROA akan turun sebesar 4.164 persen.

$\beta_{1}=0,034$, berarti bahwa variabel ROA akan meningkat sebesar 0,034 persen, apabila variabel current ratio meningkat 1 persen dengan asumsi variabel lainnya konstamn (nol).

$\beta_{2}=0,015$, berarti bahwa variabel ROA akan meningkat sebesar 0,015 persen, apabila variabel perputaran kas meningkat 1 kali dengan asumsi variabel lainnya konstamn (nol).

$\beta_{3}=0,068$, berarti bahwa variabel ROA akan meningkat sebesar 0,068 persen, apabila variabel perputaran piutang meningkat 1 kali dengan asumsi variabel lainnya konstamn (nol).

$\beta_{4}=0,199$, berarti bahwa variabel ROA akan meningkat sebesar 0,199 persen, apabila variabel perputaran persediaan meningkat 1 kali dengan asumsi variabel lainnya konstamn (nol).

Tabel 9.

Ringkasan Hasil Uji Regresi Linier Berganda

\begin{tabular}{|c|c|c|c|c|c|c|}
\hline \multirow[t]{2}{*}{ Model } & \multicolumn{2}{|c|}{$\begin{array}{l}\text { Unstandardized } \\
\text { Coefficients }\end{array}$} & \multirow[t]{2}{*}{$\mathbf{r}$} & \multirow[t]{2}{*}{$\mathbf{r}^{2}$} & \multirow[t]{2}{*}{$\mathbf{t}$} & \multirow[t]{2}{*}{ Sig. } \\
\hline & B & Std. Error & & & & \\
\hline (Constant) & -4.164 & 1.789 & & & -2.327 & .022 \\
\hline $\begin{array}{l}\text { Perputaran } \\
\text { Kas }\end{array}$ & .015 & .016 & .023 & .000529 & .969 & .335 \\
\hline $\begin{array}{l}\text { Perputaran } \\
\text { Piutang }\end{array}$ & .068 & .063 & .087 & .007569 & 1.080 & .282 \\
\hline $\begin{array}{l}\text { Perputaran } \\
\text { Persediaan }\end{array}$ & . 199 & .094 & .065 & .004225 & 2.123 & .036 \\
\hline $\begin{array}{l}\text { Current } \\
\text { Ratio }\end{array}$ & .034 & .006 & .434 & (188356. & 5.929 & .000 \\
\hline $\mathrm{F}$ & 9.236 & & & & & \\
\hline Sig. & .000 & & & & & \\
\hline $\mathrm{R}^{2}$ & .235 & & & & & \\
\hline
\end{tabular}

Pengaruh Current Ratio terhadap ROA. Nilai koefisien determinasi parsial $\left(\mathrm{r}^{2}\right)$ adalah sebesar 0,188356. Hal tersebut berarti bahwa besarnya pengaruh Current Ratio terhadap ROA secara parsial adalah $18,8356 \%$. Berdasarkan hasil analisis regresi secara parsial pengaruh Current Ratio terhadap ROA, diperoleh nilai Sig. $t$ sebesar $0,000<0,05$, yang mengindikasikan bahwa $\mathrm{H}_{1}$ diterima. Nilai koefisien beta adalah sebesar 0,034 yang berarti bahwa Current Ratio berpengaruh positif terhadap ROA.

Pengaruh Perputaran Kas terhadap ROA. Nilai koefisien determinasi parsial $\left(\mathrm{r}^{2}\right)$ adalah sebesar 0,000529. Hal tersebut berarti bahwa besarnya pengaruh Perputaran Kas terhadap ROA secara parsial adalah 0,0529\%. Berdasarkan hasil analisis regresi secara parsial pengaruh Perputaran Kas terhadap ROA, diperoleh nilai Sig. t sebesar $0,335>0,05$, yang mengindikasikan bahwa $\mathrm{H}_{2}$ ditolak. Nilai koefisien 
beta adalah sebesar 0,015 yang berarti bahwa Perputaran Kas tidak berpengaruh terhadap ROA.

Pengaruh Perputaran Piutang terhadap ROA. Nilai koefisien determinasi parsial $\left(\mathrm{r}^{2}\right)$ adalah sebesar 0,007569 . Hal tersebut berarti bahwa besarnya pengaruh Perputaran Piutang terhadap ROA secara parsial adalah 0,7569\%. Berdasarkan hasil analisis regresi secara parsial pengaruh Perputaran Piutang terhadap ROA, diperoleh nilai Sig. t sebesar 0,282 > 0,05, yang mengindikasikan bahwa $\mathrm{H}_{3}$ ditolak. Nilai koefisien beta adalah sebesar 0,068 yang berarti bahwa Perputaran Piutang tidak berpengaruh terhadap ROA.

Pengaruh Perputaran Persediaan terhadap ROA. Nilai koefisien determinasi parsial $\left(\mathrm{r}^{2}\right)$ adalah sebesar 0,004225 . Hal tersebut berarti bahwa besarnya pengaruh Perputaran Persediaan terhadap ROA secara parsial adalah 0,4225\%. Berdasarkan hasil analisis regresi secara parsial pengaruh Perputaran Persediaan terhadap ROA, diperoleh nilai Sig. $\mathrm{t}$ sebesar $0,036<0,05$, ysng mengindikasikan bahwa $\mathrm{H}_{4}$ diterima. Nilai koefisien beta adalah sebesar 0,199 yang berarti bahwa Perputaran Persediaan berpengaruh positif terhadap ROA.

Hasil penelitian ini menunjukkan bahwa Current Ratio berpengaruh positif terhadap ROA (Profitabilitas) pada Perusahaan Industri Barang Konsumsi yang terdaftar di BEI tahun 2013-2017. Temuan ini mengisyaratkan bahwa keseluruhan industri barang konsumsi bila diukur dengan tingkat Current Ratio sudah sangat efektif sehingga pengaruhnya terhadap ROA sangat tinggi. Hal ini berarti bahwa perusahaan industri barang konsumsi mampu memenuhi kewajiban jangka pendeknya dengan aktiva lancar yang dimilikinya, sehingga hasil penelitian ini sesuai dengan teori menurut Husnan (1998:440-447).

Perusahaan Industri Barang Konsumsi cenderung menginvestasikan modal kerjanya pada piutang dan persediaan, sehingga dapat meningkatkan profitabilitas perusahaan karena operasional perusahaan tetap berjalan dan meminimalisir adanya kas menganggur (idle money). Hal tersebut mendukung hasil temuan Charitou et al. (2012), Ray (2014) dan Dalayeen (2017) yang menyatakan bahwa Current Ratio berpengaruh positif dan signifikan terhadap profitabilitas (ROA).

Hasil penelitian menunjukkan bahwa Perputaran Kas memiliki hubungan yang positif namun tidak berpengaruh terhadap ROA (Profitabilitas) pada Perusahaan Industri Barang Konsumsi yang terdaftar di BEI tahun 2013-2017. Temuan ini mengisyaratkan bahwa keseluruhan industri barang konsumsi bila diukur dengan tingkat perputaran kas masih kurang efektif sehingga pengaruhnya terhadap ROA cukup sedang, hal ini disebabkan kas yang tersedia terlalu kecil untuk volume penjualan perusahaan walaupun tingkat perputaran kasnya tinggi. Hasil penelitian ini sesuai dengan teori Perputaran Kas menurut Riyanto (2001:143), sehingga mendukung hasil temuan Santhi dan Dewi (2013) serta hasil penelitian Nte'esi dan Untu (2017) yang menyatakan bahwa Perputaran Kas berpengaruh positif tetapi tidak signifikan terhadap profitabilitas (ROA).

Hasil penelitian ini menunjukkan bahwa Perputaran Piutang memiliki hubungan yang positif namun tidak berpengaruh terhadap ROA (Profitabilitas) pada Perusahaan Industri Barang Konsumsi yang terdaftar di BEI tahun 20132017. Temuan ini mengisyaratkan bahwa keseluruhan industri barang konsumsi bila diukur dengan tingkat perputaran piutang masih kurang efektif sehingga 
pengaruhnya terhadap ROA cukup sedang, hal ini disebabkan karena investasi perusahaan pada piutang yang tinggi sehingga mempengaruhi likuiditas modal kerjanya. Hasil penelitian ini sesuai dengan teori Perputaran Piutang menurut Sartono (2001:119), sehingga mendukung hasil temuan Wau (2017) dan hasil penelitian Nte'esi dan Untu (2017) yang menyatakan bahwa Perputaran Piutang berpengaruh positif tetapi tidak signifikan terhadap profitabilitas (ROA).

Hasil penelitian ini menunjukkan bahwa Perputaran Persediaan berpengaruh positif terhadap ROA (Profitabilitas) pada Perusahaan Industri Barang Konsumsi yang terdaftar di BEI tahun 2013-2017. Temuan ini mengisyaratkan bahwa keseluruhan industri barang konsumsi bila diukur dengan tingkat perputaran persediaan sudah sangat efektif sehingga pengaruhnya terhadap ROA sangat tinggi, hal ini disebabkan karena perputaran investasi perusahaan pada persediaan sangat likuid sehingga berpengaruh terhadap tingginya tingkat laba yang diperoleh perusahaan industri barang konsumsi. Hasil penelitian ini sesuai dengan teori Perputaran Persediaan menurut Sartono (2001:119), sehingga mendukung hasil temuan Ray (2014), Satriya dan Lestari (2014), Putri dan Sudiartha (2015), dan hasil penelitian Wau (2017), serta Dwiyanthi dan Sudiartha (2017) yang menyatakan bahwa Perputaran Persediaan berpengaruh positif dan signifikan terhadap profitabilitas (ROA).

\section{SIMPULAN}

Berdasarkan pokok permasalahan, hipotesis, dan hasil penelitian, maka dapat diperoleh beberapa simpulan sebagai berikut.

Likuiditas berpengaruh positif terhadap profitabilitas pada perusahaan sektor industri barang konsumsi tahun 2013-2017. Hal ini mejelaskan jika likuiditas meningkat, maka kemampuan perusahaan untuk memperoleh profitabilitas juga akan meningkat. Perputaran Kas tidak berpengaruh terhadap profitabilitas pada perusahaan sektor industri barang konsumsi tahun 2013-2017. Hal ini mejelaskan meningkatnya perputaran kas, belum tentu juga akan meningkatkan kemampuan perusahaan untuk memperoleh profitabilitas. Perputaran Piutang tidak berpengaruh terhadap profitabilitas pada perusahaan sektor industri barang konsumsi tahun 2013-2017. Hal ini mejelaskan meningkatnya perputaran piutang, belum tentu juga akan meningkatkan kemampuan perusahaan untuk memperoleh profitabilitas. Perputaran Persediaan berpengaruh positif terhadap profitabilitas pada perusahaan sektor industri barang konsumsi tahun 2013-2017. Hal ini mejelaskan jika tingkat perputaran persediaan meningkat, maka kemampuan perusahaan untuk memperoleh profitabilitas juga akan meningkat.

Beberapa saran yang dapat diberikan untuk pihak perusahaan dan peneliti selanjutnya adalah sebagai berikut. Bagi internal perusahaan, disarankan agar perusahaan lebih konsisten dalam menerapkan manjemen modal kerja. Hal tersebut karena berdasarkan teori, manajemen modal kerja memengaruhi pencapaian profitabilitas perusahaan yang merupakan tujuan utama dari operasional perusahaan. 
Penelitian ini masih memiliki beberapa kekurangan, hal tersebut dikarenakan terlalu luasnya sektor industri yang diteliti dan manajemen modal kerja setiap subsektor usaha berbeda-beda, sehingga data penelitian menjadi sangat ekstrim. Penelitian ini juga tidak memasukkan faktor eksternal ke dalam model penelitian dan hanya terbatas pada beberapa faktor internal. Peneliti selanjutnya diharapkan dapat melanjutkan penelitian serupa dengan jenis usaha yang berbeda atau dengan jenis usaha yang sama dengan membandingkan tiap-tiap subsektor usaha yang ada pada industri barang konsumsi. Memasukkan faktor-faktor eksternal yang secara teori berpengaruh terhadap profitabilitas ke dalam model penelitian juga sangat diharapkan, sehingga model memiliki kemampuan yang lebih baik dalam menjelaskan variasi dari variabel dependen.

\section{REFERENSI}

Afrifa, G. A.. \& Padachi, K. (2016). Working Capital Level Influence On SME profitability. Journal of Small Business and Enterprise Development. 23(1). 44-63. https://doi.org/10.1108/JSBED-01-2014-0014

Ahmed, Z., Awan, M. Z., Safdar, M. Z., Hasnain. T. \& Kamran, M. (2016). A Nexus Between Working Capital Management and Profitability: A Case Study of Pharmaceutical Sector in Pakistan. International Journal of Economics and Financial Issues. 6(2004). 153-160.

Ambarwati, N.S., Yuniarta, G. A. \& Sinarwati, N. K. (2015). Pengaruh Modal Kerja. Likuiditas. Aktivitas dan Ukuran Perusahaan terhadap Profitabilitas pada Perusahaan Manufaktur yang terdaftara di Bursa Efek Indonesia. EJournal S1 Ak Universitas Pendidikan Ganesha. 3(1).

Anarfi, D. \& Boateng, K.A. (2016). The Relationship between Working Capital Management and Profitability: Evidence from the Czech Agric and Forest Industry. International Refereed Research Journal. VII(3). 109-116. http://dx.doi.org/10.18843/rwjasc/v7i3/13.

Ayub, Q.M.Y. (2015). Impact of Working Capital Management on Profitability of Textile Sector of Pakistan. International Journal of Information. Business and Management. 7(1). 174-192.

Baidh, M.L. (2013). Effecte of Working Capital Management on Profitability. Interdisplinary Journal of Contemporary Research in Business, 5(2), 384390. https://doi.org/10.18178/joebm.2018.6.1.546

Barua, B., Barua, S., \& Rana, R. H. (2018). Determining the Financial Performance of Non-Life Insurers: Static and Dynamic Panel Evidence From an Emerging Economy. Journal of Developing Areas. 52(3). 153-167. Retrieved from http://search.ebscohost.com/login.aspx?direct=true \&db=ent\&AN=12628649 $9 \&$ site $=$ ehost-live 
Brigham, E. F. \& Houston, J. F. (2011). Dasar-dasar Manajemen Keuangan. Jakarta:Salemba Empat.

Bursa Efek Indonesia. (2015). Laporan Keuangan \& Tahunan Perusahaan Tercatat.http://web.idx.id/id-

id/beranda/perusahaantercatat/laporankeuangandantahunan.aspx

Bursa Efek Indonesia. (2018). Laporan Keuangan \& Tahunan Perusahaan Tercatat. Retrieved from http://www.idx.co.id/perusahaan-tercatat/laporankeuangan-dan-tahunan/.

Charitou, M., Lois, P., \& Santoso, H. B. (2012). The Relationship between Working Capital Management and Firm's Profitability: An Empirical Investigation for An Emerging Asian Country. International Business \& Economic Research Jounal. 11(8). 839-848.

Dalayeen, B.A. (2017). Working Capital Management and Profitability of Real Estate Industri in Jordan: An Empirical Study. Journal of Applied Finance \& Banking. VII(2). 49-57. Retrieved from http://gfjmr.gnu.ac.in/UserFiles/File/P5V5.pdf

Dwiyanthi, N. \& Sudiartha, G. M. (2017). Pengaruh Likuiditas dan Perputaran Modal Kerja terhadap Profitabilitas pada Perusahaan Manufaktur Sektor Industri Barang Konsumsi. E-Jurnal Manajemen Unud. 6(9). 4829-2856.

Fahmi, Irham. (2016). Pengantar Manajemen Keuangan. Cetakan kelima. Bandung: Alfabeta

Ghozali, I. 2016). Aplikasi Analisis Multivariate dengan Program IBM SPSS 23. Semarang: Badan Penerbit Universitas Diponegoro.

Handayani, T., Kristianto D., \& Astuti, D. S. P. (2016). Pengaruh Perputaran Modal Kerja. Perputaran Piutang dan Perputaran Kas terhadap Profitabilitas Perusahaan. Jurnal Akuntansi dan Sistem Teknologi Informasi. 12(2). 259265

Hartono, J. (2013). Metodologi Penelitian Bisnis (Salah Kaprah dan PengalamanPengalaman). Yogyakarta: BPFE YOGYAKARTA

Hoang, T. V. (2015). Impact of Capital Management on Firm Profitability: The Case of Listed Manufacturing Firms on HO. Asian Economic and Financial Review $5(5)$. 779-789. https://doi.org/10.18488/journal.aefr/2015.5.5/102.5.779.789

Horne, J. C. V. \& Wachowicz, J. M. (2012). Prinsip-Prinsip Manajemen Keuangan. Jakarta: Salemba Empat. 
Husnan, S. \& Pudjiastuti, E. (2012). Dasar-dasar Manajemen Keuangan. Yogyakarta: UPP STIM YKPN

Jusup, H. A. (2005). Dasar-Dasar Akuntansi. Yogyakarta: Akademi Akuntansi YKPN.

Martono \& Hajrito. A. (2003). Manajemen Kuangan. Yogyakarta: EKONISIA.

Marusya \& Magantar, M. (2016). Pengaruh Struktur Modal Terhadap Profitabilitas Pada Perusahaan Tobacco Manufacturers yang Terdaftar Di Bursa Efek Indonesia (BEI) Periode 2008-2015. Jurnal Berkala Ilmiah Efisiensi. 16(03). 484-492.

https://ejournal.unsrat.ac.id/index.php/jbie/article/view/13452/13035

Munawir. (2001). Analisa Laporan Keuangan dan Manajemen. Edisi Pertama. Yogyakarta: BPFE YOGYAKARTA

Naveen, Ch. (2014). Working Capital Management of Glaxo SmithKline Consumer Health Care : An Empirical Study. Institute of Public Enterprise Journal Of Management. 4(2). 106-118.

Nte'esi, E. \& Untu, V. N. (2017). Analisis Pengaruh Perputaran Modal Kerja Terhadap Profitabilitas Perusahaan Pada Pt . Indofood Sukses Makmur . Tbk Periode 2011-2015. Jurnal EMBA. 5(2). 289-297. https://doi.org/2303-1174

Putri, P. I. G., \& Sudiartha, G. M. (2015). Pengaruh Modal Kerja Terhadap Profitabilitas Perusahaan Food and Beverages. E-Jurnal Manajemen Unud, 4(2), 511-523. https://doi.org/10.14414/jbb.v5i1.379

Raharjaputra, H. S. (2009). Manajemen Keuangan dan Akuntansi. Cetakan Pertama. Jakarta: Salemba Empat.

Ray, K. K. (2014). Efficiency of Working Capital Management and Profitability: A Case of Hindalco. Review of Management. 4(1). 19-30.

Riyanto, B. (2001). Dasar-Dasar Pembelanjaan Perusahaan. Yogyakarta: BPFEYOGYAKARTA.

Santhi, I. G. A. P. I. W., \& Dewi, S. K. S. (2013). Pengaruh Manajemen Modal Kerja Terhadap Tingkat Profitabilitas Pada Perusahaan Makanan Dan Minuman Yang Terdaftar Di Bursa Efek Indonesia Periode 2012-2013, 35223539 .

Sarbapriya. (2012). Evaluating The Impact of Working Capital Management Components on Corporate Profitability: Evidence From Indian Manufacturing Firm. International Journal of Economic Practices and Theories. 
http://www.ijept.org/index.php/ijept/article/view/Evaluating_the_Impact_of _Working_Capital_Management_Components_on_Corporate_Profitability.

Sartono, A. (2001). Manajemen Keuangan Teori dan Aplikasi. Yogyakarta:BPFE YOGYAKARTA.

Satriya, I. M. D., \& Lestari, P. V. (2014). Pengaruh Perputaran Modal Kerja terhadap Profitabilitas Perusahaan. E-Jurnal Manajemen Universitas Udayana, 3(7), 1927-1942.

Singh, H.P. \& Kumar, S. (2017). Working Capital Management and Firm Profitability: A Meta-Analysis. Emerald Publishing Limited. 9(1). 34-47. DOI:10.1108/QRFM-06-2016-0018

Sugiyono. 2016. Metode Penelitian Manajemen. Bandung:Alfabeta.

Sulindawati, N. L. G. E., Yuniarta, G. A., \& Purnamawati, I. G A. (2017). Manajemen Keuangan: Sebagai Dasar Pengambilan Keputusan Bisnis. Depok: Rajawali Press.

Tran, H., Abbott. M., \& Jin Yap, C. (2017). How Does Working Capital Management Affect the Profitability of Vietnamese Small and Medium Sized Enterprises? Journal of Small Business and Enterprise Development. 24(1). 211. https://doi.org/10.1108/JSBED-05-2016-0070

Tsagem, M. M. (2014). Impact of Working Capital Management and Corporate Governance on the Profitability of Small and Medium-Sized Entities in Nigeria : A Proposed Model. International Journal of Science Commerce and Humanities. 2(5). 53-65.

Utama, M. S. (2016). Aplikasi Analisis Kuantitatif (Untuk Ekonomi dan Bisnis). Denpasar: CV. Sastra Utama.

Utami, M.S. dan Dewi, M.R. (2016). Pengaruh Manajemen Modal Kerja terhadap Profitabilitas Perusahaan Manufaktur yang terdaftar di Bursa Efek Indonesia. E-Jurnal Manajemen Unud. 5(6). 3476-3503.

Wau, R. (2017). Analisis Efektifitas Modal Kerja Dan Pengaruhnya Terhadap Profitabilitas. Journal of Business Studies, 2(1), 61-74. Retrieved from https://www.google.co.id/url? sa $=\mathrm{t} \& \mathrm{rct}=\mathrm{j} \& \mathrm{q}=\& \mathrm{esrc}=\mathrm{s} \&$ source= $=$ web\&cd=2\& $\mathrm{cad}=\mathrm{rja} \& u a c t=8 \& \mathrm{ved}=0$ ahUKEwitma35 1 ovXAhUESY8KHZL6CWsQFggp MAE\&url=http\%3A\%2F\%2Fjournal.uta45jakarta.ac.id\%2Findex.php\%2Fjb suta\%2Farticle\%2Fdownload\%2F791\%2F509\&usg=AOvVaw2fsr9TowRbm Gi-G-OS-cO.

Wiagustini, N. L. P. (2014). Manajemen Keuangan. Denpasar: Udayana University Press. 